\title{
EVALUASI EFIKASI DAN KONTROL LOCUS PENGGUNA TEKNOLOGI SISTEM BASIS DATA AKUNTANSI
}

\author{
Fikri Hamidy
}

\author{
Sistem Informasi, Universitas Teknokrat Indonesia \\ Jl. H.ZA Pagaralam, No 9-11, Labuhanratu,Bandarlampung \\ e_mail: fikrihamidy@teknokrat.ac.id
}

\begin{abstract}
This research aims to empirically investigate the influences of the personality factors towards the students' intention to use the database software at the computerized accounting vocational colleges in Lampung province. In order to answer the hypotheses, this research applies a survey study with 301 computerized accounting vocational students. Based on these samples I test using structural equation modeling of AMOS ${ }^{\mathrm{TM}}$ (Analysis of Moment Structure) software.

The result of the study indicates that the estimations of the regression weights coefficient, standardized regression weights and critical ratio, has led to the conclusion that statistically, the first hypothesis is not supported whereas the second hypothesis is statistically supported. In conclusion, , based on the low score of the standardized regression wights coefficient, it can be concluded thus, that the students' intention to use the database software at the computerized accounting vocational colleges in Lampung Province is relatively low.
\end{abstract}

Key Words : $\quad$ personality, intention, database software

\section{Pendahuluan}

Individu-individu pengguna TI dihasilkan dari pendidikan dan pelatihan pengguna TI diantaranya adalah berasal dari pendidikan vokasi terapan. Undang-undang RI Nomor 12 (UU 12) Tahun 2012 tentang Pendidikan Tinggi dinyatakan pada paragraf 2 pasal 16 ayat 1 bahwa, "Pendidikan vokasi merupakan pendidikan tinggi program diploma yang menyiapkan mahasiswa untuk pekerjaan dengan keahlian terapan tertentu sampai program sarjana terapan". Kurikulum diploma 3 tahun (D3) vokasi komputerisasi akuntansi disusun dalam usaha menyiapkan mahasiswa untuk dapat menggunakan sistem dan teknologi informasi sesuai dengan kompetensi di bidangnya.

Sistem informasi akuntansi (SIA) yang merupakan suatu rerangka pengkordinasian sumber daya (data, meterials, equipment, suppliers, personal, and funds) untuk mengkonversi input berupa data ekonomik menjadi output berupa informasi keuangan yang digunakan untuk melaksanakan kegiatan suatu entitas dan menyediakan informasi akuntansi bagi pihak-pihak yang berkepentingan (Wilkinson, 2000). Basis data pada suatu sistem informasi dan aplikasi komputer memiliki fungsi yang sangat penting dalam menghasilkan informasi akuntansi yang bermanfaat.

Dalam silabus mata kuliah sistem informasi akuntansi dan basis data, mahasiswa vokasi komputerisasi akuntansi diharapkan dapat memahami dan dapat mengaplikasikannya dalam prototype perancangan basis data akuntansi (database accounting). Pemanfaatan perangkat lunak basis data (database software) oleh mahasiswa vokasi komputerisasi akuntansi diunjukkan pada kompetensi keahlian rancang bangun aplikasi sistem yang biasa digunakan yaitu: MySQL ${ }^{\mathrm{TM}}$, PostgreSQL ${ }^{\mathrm{TM}}$, SQLite ${ }^{\mathrm{TM}}$, Microsoft SQL ServerTM, Microsoft Access ${ }^{\mathrm{TM}}$, Oracle $^{\mathrm{TM}}$, Sybase ${ }^{\mathrm{TM}}$, dBASE ${ }^{\mathrm{TM}}$, FoxPro ${ }^{\mathrm{TM}}$, atau menggunakan IBM DB2 ${ }^{\mathrm{TM}}$.

Kompetensi keahlian rancang bangun aplikasi sistem informasi akuntansi memerlukan niat (intention) untuk menggunakan perangkat lunak pendukung. Upaya yang diperlukan oleh mahasiswa vokasi komputerisasi akuntansi untuk memiliki kompetensi pemrograman basis data diawali dengan kemampuan penggunaan perangkat lunak basis data. Upaya ini tentu mempengaruhi masa penyelesaian tugas akhir mahasiswa yang bersangkutan.

Penelitian ini berbeda dari penelitian sebelumnya dalam instrument pengukuran dan populasinya. Analisis personality menggunakan instrument penelitian khas sistem informasi yaitu berupa computer self-efficacy dan computer locus of control Populasinya adalah mahasiswa sebagai pengguna perangkat lunak basis data yang merupakan mahasiswa semester akhir pada perguruan tinggi penyelenggara vokasi komputerisasi akuntansi di Propinsi Lampung.

\section{Kajian Pustaka dan Kerangka Pemikiran}

Teori yang melandasi penelitian intention menggunakan perangkat lunak basis data pada mahasiswa vokasi komputerisasi akuntansi di Propinsi Lampung adalah dari teori psikologi, sosial dan teori informasi. Teori-teori ini telah digunakan secara meluas dalam penelitian multi disiplin keilmuan. Penelitian pada bidang ilmu akuntansi juga menggunakannya seperti pada tabel 2.1 tentang penelitian terdahulu.

Dalam psikologi, teori Trait (sifat) adalah sebuah pendekatan tentang personality manusia. Teori Trait terutama adalah memfokuskan terhadap pengukuran sifat, yang dapat didefinisikan sebagai pola kebiasaan perilaku, pikiran, dan emosi (Kassin, 2003). Locus of control adalah teori dalam psikologi kepribadian mengacu pada sejauh mana orang percaya bahwa mereka dapat mengontrol peristiwa yang mempengaruhi mereka. Pemahaman konsep ini dikembangkan oleh Julian Rotter B. pada tahun 1954, dan sejak itu menjadi salah satu aspek penelitian personality atau kepribadian. Locus dikonsepkan menjadi locus internal dan locus eksternal. Locus internal adalah kepercayaan seseorang bahwa dirinya bisa mengendalikan hidupnya sendiri. Sedangkan locus eksternal adalah seseorang yang mempercayai 
bahwa keputusan dan kehidupannya dikendalikan oleh faktor lingkungan diluar kendalinya.

\subsection{Computer Self-Efficacy}

Delcourt dan Kinzie (1993) mendefinisikan computer self-efficacy sebagai ukuran kepercayan diri pengguna komputer dengan kemampuan mereka untuk memahami, menggunakan, dan menerapkan pengetahuan dan keterampilan komputer.

Para penulis menemukan bahwa individu yang memiliki computer self-efficacy yang tinggi akan merasa kompeten dalam menggunakan perangkat keras dan perangkat lunak komputer yang berbeda. Namun, rendahnya computer self-efficacy mengarah ke keyakinan bahwa individu akan mengalami kesulitan dalam menggunakan hardware dan software komputer. Berdasarkan paparan tersebut, maka hipotesis pertama yang diajukan dalam penelitian ini adalah:

H1: Computer Self-efficacy berpengaruh positif terhadap Intention penggunaan perangkat lunak basis data.

\subsection{Computer Locus of Control}

Locus of control merupakan keyakinan individu bahwa individu bisa mempengaruhi kejadian-kejadian yang berkaitan dengan kehidupannya. Menurut Rotter (1966) locus of control terdiri dari dua bagian yaitu internal locus of control dan external locus of control. Internal locus of control adalah individu yang meyakini bahwa apa yang terjadi selalu berada dalam kontrolnya, dan selalu mengambil peran serta tanggung jawab dalam setiap pengambilan keputusan. Mereka mengendalikan apa yang terjadi pada diri mereka. Kaum internal lebih aktif mencari informasi sebelum mengambil keputusan, dan lebih termotivasi untuk berprestasi, serta melakukan upaya yang lebih besar untuk mengendalikan lingkungan mereka Sedangkan external locus of control adalah individu yang meyakini bahwa kejadian dalam hidupnya berada di luar kontrolnya, yang melihat bahwa apa yang terjadi pada diri mereka dikendalikan oleh kekuatan luar, seperti misalnya kemujuran dan peluang (Rotter, 1966).

Kay (1990) melakukan penelitian menggunakan dimensi yang dikembangkan dari general Locus of Control (Rotter, 1966) untuk mengukur asosiasi locus of control terhadap computer literacy. Ditemukan bahwa locus of control berpengaruh terhadap computer literacy pengguna. Dimensi yang dikembangkan Kay (1990) disebut sebagai Computer Locus of Control Measured (CLOM). Dalam penelitian ini CLOM digunakan sebagai instrument personality trait. Hipotesis kedua yang diajukan sejalan dengan uraian di atas adalah sebagai berikut:

H2 : Computer Locus of Control berpengaruh terhadap Intention penggunaan perangkat lunak basis data.

\subsection{Basis Data dan Database Management System}

Basis data adalah kumpulan data yang terhubung secara logical, terdeskripsi dari data yang dirancang untuk memenuhi kebutuhan informasi dari sebuah organisasi. Basis data merupakan sebuah tempat pengumpulan data yang sangat besar yang digunakan secara bersama-sama oleh berbagai departemen (Whitten, et al., 2004). Sistem basis data adalah sistem menyimpan informasi dan memungkinkan penggunanya mengambil dan mengubah informasi itu saat diperlukan. Komponen-komponen penting sistem basis data adalah: data, perangkat keras (hardware), perangkat lunak (software), dan pengguna (user) yang dikategorikan sebagai Administrator, Programmer dan End-user.

Database Management System (DBMS) dirancang khusus sebagai aplikasi yang berinteraksi dengan pengguna, dengan aplikasi lain, dan dengan basis data (database) itu sendiri untuk menangkap dan menganalisa data. DBMS adalah perangkat lunak khusus yang digunakan untuk membuat, mengontrol dan mengelola basis data (Whitten, et al., 2004). DBMS antara lain adalah: MySQL ${ }^{\mathrm{TM}}$, PostgreSQL ${ }^{\mathrm{TM}}$, SQLite ${ }^{\mathrm{TM}}$, Microsoft SQL Server ${ }^{\mathrm{TM}}$, Microsoft Access ${ }^{\mathrm{TM}}$, Oracle ${ }^{\mathrm{TM}}$, Sybase ${ }^{\mathrm{TM}}$, dBASETM $^{\mathrm{T}}$, FoxPro ${ }^{\mathrm{TM}}$, dan IBM DB2 ${ }^{\mathrm{TM}}$.

\section{Metode dan Pendekatan}

\subsection{Populasi dan Sampel}

Populasi merupakan jumlah keseluruhan elemen yang diteliti (Cooper dan Schindler, 2003). Dengan demikian populasi adalah individu yang memiliki informasi yang menjadi fokus penelitian. Populasi dalam penelitian ini adalah menggunakan populasi mahasiswa vokasi komputerisasi akuntansi pada Perguruan Tinggi (PT) di Propinsi Lampung yang terakreditasi Badan Akreditasi Nasional Perguruan Tinggi (BAN-PT).

Metode pengambilan sampel yang digunakan dalam penelitian ini adalah secara non probabilitas yaitu convenience sampling. Data primer yang didapat dari convenience sampling oleh mahasiswa vokasi komputerisasi akuntansi di Propinsi Lampung adalah atas dasar sukarela. Mahasiswa secara sukarela meluangkan waktu untuk mengisi kuisioner dan berusaha memberikan jawaban menurut persepsinya masing-masing. Sebelum mengisi kuisioner para mahasiswa diberikan pengarahan tentang maksud, tujuan dan teknis pengisian kuisioner.

\subsection{Sumber dan Teknik Pengumpulan Data}

Teknik yang digunakan dalam pengumpulan data penelitian adalah menggunakan data primer untuk mendapatkan data opini individu melalui kuesioner yang berisi daftar pertanyaan mengenai semua variabel yang diteliti yaitu : computer self-efficacy, computer locus of control dan profil demografi dari mahasiswa vokasi komputerisasi akuntansi.

Peneliti meminta ijin kepada pimpinan masingmasing institusi untuk melibatkan beberapa dosen pengampu mata kuliah yang mengajarkan perangkat lunak basis data. Para dosen diminta secara sukarela untuk terlibat menjaring responden, mengarahkan, dan mendapatkan informasi melalui pengisian kuisioner.

\subsection{Definisi Operasional dan pengukuran Variabel}

Computer Self-Efficacy (CSE) skala Likert mulai poin 1 yang menyatakan sangat tidak setuju sampai dengan poin 5 yang menyatakan sangat setuju. Variabel ini diukur dengan menggunakan sepuluh pertanyaan. Pertanyaan-pertanyaan ini diadopsi dari penelitian yang 
dilakukan oleh Compeau dan Higgins (1991) yang sering disebut dimensi skala Computer Self-Efficacy (CSE).

Pertanyaan tentang Computer Locus of Control diukur dengan Dimensi skala Rotter yang dikembangkan oleh Kay (1990) yang terdiri dari 10 item yang diukur dengan skala Likert mulai poin 1 yang menyatakan sangat tidak setuju sampai dengan poin 5 yang menyatakan sangat setuju.

Niat (intention) didefinisikan sebagai keinginan untuk melakukan sesuatu. Niat diukur dengan skala Likert mulai poin 1 yang menyatakan sangat tidak setuju sampai dengan poin 5 yang menyatakan sangat setuju. Variabel ini diukur dengan menggunakan 2 pertanyaan. Pertanyaan-pertanyaan ini diadopsi dari penelitian yang dilakukan oleh Davis (1989).

\subsection{Pengujian Instrumen Penelitian}

Pengujian instrumen penelitian adalah bagian yang terpenting untuk dilakukan. Data penelitian tidak berguna jika instrumen pengukuran yang digunakan tidak mempunyai validitas dan reliabilitas yang tinggi, pengujian hipotesis sangat dipengaruhi oleh kualitas data (Cooper dan Schindler, 2003). Sebelum dilakukan survei, maka terlebih dahulu dilakukan pra survei dengan sampel yang lebih kecil dengan tujuan untuk mengetahui validitas dan reliabilitas instrumen yang ada, sehingga dapat digunakan untuk memperbaiki item-item pertanyaan yang memenuhi persyaratan tersebut sebelum dilakukan survei yang sesungguhnya. Meskipun item-item pertanyaan yang digunakan dalam penelitian ini telah digunakan pada penelitian sebelumnya dan dinyatakan valid serta reliabel, tetapi item-item pertanyaan ini perlu diuji kembali validitas dan reliabilitasnya.

\subsection{Uji Validitas dan Uji Reliabilitas}

Uji validitas ini dilakukan untuk mengetahui sejauh mana kemampuan instrumen penelitian mengukur apa yang seharusnya diukur (Cooper dan Schindler, 2003). Validitas internal terdiri dari validitas isi dan validitas konstruk. Pengukuran validitas secara kualitatif dilakukan dengan content validity dan uji validitas secara kuantitatif dengan Confirmatory Faktor Analysis (CFA) melalui bantuan software SPSSTM for Windows, yang menggambarkan validitas konstruk (Ghozali, 2005).

Validitas konstruk menunjukkan seberapa baik hasil yang diperoleh dari penggunaan suatu pengukuran sesuai teori-teori yang digunakan untuk mendefenisikan suatu konstruk (Hartono, 2004). Instrument memiliki convergent validity jika item pengukuran memiliki faktor loading lebih besar dari 0,4 (Hair et al., 2006). Hair et al., (2006) juga menyatakan bahwa faktor loading lebih besar 0,3 dapat dipertimbangkan sebagai batas minimal dan bila faktor loading lebih besar dari 0,5 maka diterima secara signifikan.

Reliabilitas adalah suatu alat pengukur yang menunjukkan akurasi, konsistensi dan ketepatan dari pengukurnya (Hartono, 2004). Konsistensi menunjukkan seberapa baik item-item pertanyaan yang mengukur sebuah konsep bersatu menjadi sebuah kumpulan. Suatu kuisioner dikatakan reliabel atau handal jika jawaban seseorang terhadap pertanyaan adalah konsisten dari waktu ke waktu (Cooper dan Schindler, 2003). Dalam penelitian ini, uji reliabilitas dilakukan dengan menggunakan teknik Cronbach's Alphadengan bantuan software SPSS ${ }^{\text {TM }}$ for Windows (Ghozali, 2005). Cronbach's Alphaadalah koefisien keandalan yang menunjukkan seberapa baik item dalam suatu kumpulan secara positif berkorelasi satu sama lain. Konsistensi jawaban ditunjukan oleh nilai rule of thumb atau tingginya cronbach's alpha, dengan nilai alpha harus lebih besar dari 0,7 meskipun nilai 0,6 masih dapat diterima (Hair et al., 2006).

\subsection{Pengujian Hipotesis}

Di dalam analisis data penelitian digunakan metode statistika. Seluruh perhitungan statistika dilakukan dengan menggunakan bantuan perangkat lunak statistik yaitu IBM ${ }^{\circledR}$ SPSS ${ }^{\circledR}$ Statistcs ${ }^{\text {TM }} 21$ dan IBM ${ }^{\circledR}$ SPSS $®$ AMOS $^{\text {TM }}$ versi 21 for Windows ${ }^{\mathrm{TM}}$. Tingkat signifikansi yang digunakan dalam penelitian ini adalah sebesar 0,05 (5\%). Dari hasil uji hipotesis diketahui apakah hipotesis diterima atau hipotesis ditolak. Pada tabel 3.1 dibawah ini adalah merupakan hipotesis penelitian yang di uji pada bab empat, melalui proses melalui pendekatan SEM berbasis covariance dengan bantuan perangkat lunak IBM ${ }^{\circledR}$ SPSS ${ }^{\circledR}$ AMOS $^{\mathrm{TM}}$ versi 21 .

Tabel 3.1. Hipotesis yang diajukan

\begin{tabular}{|c|l|}
\hline No. & \multicolumn{1}{|c|}{ Hipotesis } \\
\hline H1 & $\begin{array}{l}\text { Computer Self-efficacy (CSE) berpengaruh positif } \\
\text { terhadap Intention penggunaan perangkat lunak basis } \\
\text { data (ITU) }\end{array}$ \\
\hline $\mathbf{H 2}$ & $\begin{array}{l}\text { (Internal) Computer Locus of Control (CLOC) } \\
\text { berpengaruh positif terhadap Intention penggunaan } \\
\text { perangkat lunak basis data (ITU) }\end{array}$ \\
\hline
\end{tabular}

Cara untuk menguji hipotesis penelitian salah satunya adalah dengan membandingkan Critical Ratio (C.R.) yang dihasilkan model atau yang disebut t_hitung dibandingkan dengan Critical Value atau nilai kritis atau yang biasa disebut sebagai t_tabel. Pada penelitian ini uji dengan signifikansi 5\% sehingga t_tabelnya adalah 1,625. Jika t_hitung > t_tabel maka hipotesis terdukung. Sebaliknya jika t_hitung<t_tabel maka hipotesis tidak terdukung. Gambar 3.1. menunjukkan model penelitian awal disederhanakan. berikut:

Persamaan dalam penelitian adalah sebagai

$\mathrm{Yi}=\alpha+\beta 1 \mathrm{X} 1+\mathrm{ei} \ldots \ldots .(1)$

$\mathrm{Yi}=\alpha+\beta 2 \mathrm{X} 2+\mathrm{ei} \ldots \ldots .(2)$;

Keterangan:

$\mathrm{Yi}=$ Intention to Use (dependent variable)

$\mathrm{X} 1=$ Computer Self-efficacy (independent variable)

$\mathrm{X} 2=$ Computer Locus of Control (independent variable)

$\alpha=$ Konstanta (nilai Yi apabila $\mathrm{X}=0$ )

$\beta=$ Koefisien regresi (nilai peningkatan ataupun penurunan)

$\mathrm{ei}=$ disturbance errors (variabel pengganggu). 
Pengujian hipotesis dilakukan dengan SEM (Structural Equation Modeling) dengan software IBM $®$ SPSS ${ }^{\circledR}$ AMOS $^{\mathrm{TM}}$ (Analysis of Moment Structure) versi 21. SEM merupakan sekumpulan teknik-teknik statistical yang memungkinkan pengujian sebuah rangkaian hubungan relatif rumit secara simultan. Ukuran sampel yang harus dipenuhi dalam permodelan ini adalah minimum berjumlah 100. Dalam sebuah analisis SEM mensyaratkan minimum 100 sampel. Observasi yang muncul dengan nilai-nilai ekstrim, baik secara univariat maupun multivariat yaitu yang muncul karena kombinasi karakteristik unik yang dimilikinya dan terlihat sangat jauh berbeda dari observasi-observasi lainnya. Pengujian tentang ada tidaknya outliers univariate dilakukan dengan menganalisis nilai $\mathrm{Z}$ score dari data penelitian yang digunakan. Apabila terdapat nilai $\mathrm{Z}$ score yang berada pada rentang lebih besar dari pada \pm 4 (Hair et al, 1995) maka hal ini berarti termasuk dalam kategori outliers sedangkan pengujian outliers pada tingkat multivariate dapat dilihat dari jarak mahalanobis (mahalanobis distance).

Normalitas dapat diuji dengan melihat gambar histogram data atau dapat diuji dengan metode-metode statistik. Uji normalitas ini perlu dilakukan baik untuk normalitas terhadap data tunggal maupun normalitas multivariate dimana beberapa variabel digunakan sekaligus dalam analisis akhir. Pengujian normalitas dalam penelitian ini dilakukan dengan memberikan perintah test of normality and outliers. Asumsi normalitas ditolak bila nilai C.R lebih besar dari nilai kritis yaitu \pm 2,58 .

Menurut Ferdinan (2002) seperti yang disajikan pada tabel 3.1, bahwa kriteria dalam mengevaluasi model dan pengaruh pengaruh yang ditampilkan dalam model adalah $\chi^{2}$ Chi Square Statistics, Significance probability, CMIN/DF, GFI, AGFI, TLI, CFI dan RMSEA yang memenuhi syarat indeks yang ditetapkan. Dinyatakan bahwa $\chi^{2}$ Chi Square Statistic jika semakin kecil nilai $\chi^{2}$ semakin baik model itu dan diterima berdasarkan probabilitas dengan cut off value sebesar $\mathrm{p}>0,05$ atau $\mathrm{p}>0,01$.

CMIN/DF atau square relatif merupakan hasil pembagian antara fungsi kesalahan sampel yang minimal dengan derajat kebebasannya yang digunakan untuk mengukur fit model. CMIN/DF yang diharapkan agar model dapat diterima adalah $\leq 2,00$. Pengujian indeks GFI (Goodness Fit of Index) dimaksudkan untuk mengatahui proporsi tertimbang dari varians dalam matriks kovarians sampel yang dijelaskan oleh matriks kovarians populasi yang terestimasi, GFI yang diharapkan adalah GFI $\geq 0,90$.

AGFI (Adjusted Goodness Fit Index) dapat mennyesuaikan fit indeks terhadap df yang tersedia untuk menguji diterima atau tidaknya model. Hasil yang diharapkan AGFI adalah $\geq 0,90$. Sedangkan TLI (Tucker Lewis Index) adalah sebuah alternatif incremental fit index yang membandingkan sebuah model yang diuji terhadap sebuah base line model. Nilai yang diharapkan adalah TLI $\geq 0,95$

Rentang CFI (Comparative Fit Index) sebesar 01 dimana semakin mendekati 1 mengindikasikan tingkat fit yang paling tinggi, a very good fit nilai yang diharapkan adalah CFI $\geq 0,95$. Kemudian mengukur
RMSEA (the Root Meansquare Error of Approximation) adalah merupakan sebuah indeks yang dapat digunakan untuk mengkompensasi chi square dalam sampel besar, nilai RMSEA yang kecil atau sama dengan 0,08 merupakan indeks untuk dapat diterimanya model yang menunjukkan sebuah close fit dari model tersebut berdasarkan degress.

Tabel 3.2

Asumsi-asumsi dalam Pengujian SEM

\begin{tabular}{|c|c|}
\hline Goodness of Fit Index & Cut of Value \\
\hline$\chi^{2}$ Chi Square Statistics & Diharapkan kecil \\
\hline Significance probability & $\geq 0,05$ \\
\hline CMIN/DF & $\leq 2,00$ \\
\hline GFI & $\geq 0,90$ \\
\hline TLI & $\geq 0,95$ \\
\hline RMSEA & $\leq 0,08$ \\
\hline
\end{tabular}

( Sumber : Ferdinand, 2002 )

\subsection{Penelitian Uji Coba}

Uji coba penelitian terhadap 43 mahasiswa vokasi komputerisasi akuntansi yang dilaksanakan pada tanggal 25 Juni 2013. Uji coba ini bertujuan untuk mengukur validitas dan reliabilitas kuisioner. Dari pengujian validitas dengan perangkat lunak IBM ${ }^{\circ}$ SPSS $®$ Statistics 21 TM didapat hasil bahwa: butir CSE1; CSE2; CSE3; CSE7;CSE8; CSE10; CLOC3; CLOC6; CLOC8; CLOC9; CLOC10; PEOU2 dan PEOU4 adalah tidak valid sedangkan yang lainnya valid (tabel 3.2.). Butir (item) yang tidak valid dalam uji coba akan dikeluarkan dalam pengujian hipotesis Confirmatory Factor Analysis (CFR).

Pada penelitian dengan sampel besar, butir-butir pertanyaan yang valid digunakan dalam analisis untuk menguji hipotesis yang diajukan. Butir-butir yang valid adalah: CSE4; CSE5; CSE6; CSE9; CLOC1; CLOC2; CLOC4; CLOC5; CLOC7; ITU1 dan ITU2 (tabel 3.3). Semua analisis menggunakan IBM $®$ SPSS $®$ Statistics dan IBM ${ }^{\circledR}$ SPSS ${ }^{\circledR}$ AMOSTM $^{\text {TM }}$ versi 21.

Reliabilitas terhadap kelima variabel pada sampel kecil dengan jumlah butir (item) sebanyak 34 pertanyaan secara keseluruhan adalah Cronbach's Alpha masih di atas 0,600 yang dianggap masih bisa diterima/reliable (Hair et al., 2006) seperti yang terdapat pada tabel 3.3.

Tabel 3.3.

Validitas Kuisioner Uji Coba Sampel Kecil

\begin{tabular}{|c|c|c|c|c|}
\hline No. & Butir(Item) & Rhitung & $\begin{array}{c}\text { Rtabel } \\
\text { ts. 0,05 }\end{array}$ & $\begin{array}{c}\text { Keterangan } \\
\text { (Rhitung>= } \\
\text { Rtabel) }\end{array}$ \\
\hline 1 & CSE1 & 0,192 & 0,301 & Tidak Valid \\
\hline 2 & CSE2 & 0,240 & 0,301 & Tidak Valid \\
\hline 3 & CSE3 & 0,178 & 0,301 & Tidak Valid \\
\hline 4 & CSE4 & 0,476 & 0,301 & Valid \\
\hline 5 & CSE5 & 0,446 & 0,301 & Valid \\
\hline 6 & CSE6 & 0,648 & 0,301 & Valid \\
\hline
\end{tabular}




\begin{tabular}{|c|c|c|c|c|}
\hline 7 & CSE7 & 0,223 & 0,301 & Tidak Valid \\
\hline 8 & CSE8 & 0,159 & 0,301 & Tidak Valid \\
\hline 9 & CSE9 & 0,579 & 0,301 & Valid \\
\hline 10 & CSE10 & 0,260 & 0,301 & Tidak Valid \\
\hline 11 & CLOC1 & 0,494 & 0,301 & Valid \\
\hline 12 & CLOC2 & 0,492 & 0,301 & Valid \\
\hline 13 & CLOC3 & 0,205 & 0,301 & Tidak Valid \\
\hline 14 & CLOC4 & 0,514 & 0,301 & Valid \\
\hline 15 & CLOC5 & 0,456 & 0,301 & Valid \\
\hline 16 & CLOC6 & 0,257 & 0,301 & Tidak Valid \\
\hline 17 & CLOC7 & 0,574 & 0,301 & Valid \\
\hline 18 & CLOC8 & $(0,110)$ & 0,301 & Tidak Valid \\
\hline 19 & CLOC9 & 0,184 & 0,301 & Tidak Valid \\
\hline 20 & CLOC10 & 0,233 & 0,301 & Tidak Valid \\
\hline 21 & ITU1 & 0,477 & 0,301 & Valid \\
\hline 24 & ITU2 & 0,477 & 0,301 & Valid \\
\hline
\end{tabular}

Pengujian validitas pada penelitian ini bertujuan untuk menemukan item/indikator (konstruk) kuisioner yang akan digunakan sebagai data analisis pada sampel besar. Setelah dikoreksi jumlah item yang digunakan berjumlah 21 item seperti yang dirangkum pada tabel 3.4. berikut ini:

Tabel 3.4.

Validitas Kuisioner Uji Coba Sampel Kecil yang Disesuaikan

\begin{tabular}{|c|c|c|c|c|}
\hline No. & $\begin{array}{c}\text { Butir } \\
(\text { Item })\end{array}$ & $\begin{array}{c}\text { Rhitu- } \\
\text { ng }\end{array}$ & $\begin{array}{c}\text { Rtabel } \\
\text { ts. 0,05 }\end{array}$ & $\begin{array}{c}\text { Keterangan } \\
\text { (Rhitung>= } \\
\text { Rtabel) }\end{array}$ \\
\hline 1 & CSE4 & 0,342 & 0,301 & Valid \\
\hline 2 & CSE5 & 0,337 & 0,301 & Valid \\
\hline 3 & CSE6 & 0,630 & 0,301 & Valid \\
\hline 4 & CSE9 & 0,631 & 0,301 & Valid \\
\hline 5 & CLOC1 & 0,427 & 0,301 & Valid \\
\hline 6 & CLOC2 & 0,635 & 0,301 & Valid \\
\hline 7 & CLOC4 & 0,742 & 0,301 & Valid \\
\hline 8 & CLOC5 & 0,644 & 0,301 & Valid \\
\hline 9 & CLOC7 & 0,401 & 0,301 & Valid \\
\hline 10 & ITU1 & 0,477 & 0,301 & Valid \\
\hline 11 & ITU2 & 0,477 & 0,301 & Valid \\
\hline
\end{tabular}

Analisis dan hasil yang akan diuraikan pada bab berikutnya adalah menggunakan tiga variabel (CSE, CLOC, dan ITU) dengan 11 butir (item) pertanyaan didasari hasil uji validitas dan reliabilitas pada sampel kecil. Dengan menggunakan item yang valid meningkatkatka Cronbach's Alpha seperti pada tabel 3.5, reliabilitas CSE dan CLOC meningkat diatas reliabilitas sebelumnya.

Tabel 3.5.

Uji Reliabilitas pada Sampel Kecil yang Disesuaikan

\begin{tabular}{|c|c|c|c|}
\hline Variabel & $\begin{array}{c}\text { Cronbach' } \\
\text { s Alpha }\end{array}$ & $\begin{array}{c}\text { N Butir } \\
\text { (Item) }\end{array}$ & $\begin{array}{c}\text { Kete- } \\
\text { rangan }\end{array}$ \\
\hline $\begin{array}{c}\text { Computer Self- } \\
\text { Efficacy (CSE) }\end{array}$ & 0,692 & 4 & Reliabel \\
\hline $\begin{array}{c}\text { Computer Locus } \\
\text { of Control }\end{array}$ & 0,787 & 5 & Reliabel \\
\hline
\end{tabular}

\begin{tabular}{|c|c|c|c|}
\hline (CLOC) & & \\
\hline $\begin{array}{c}\text { Intention to Use } \\
\text { (ITU) }\end{array}$ & 0,617 & 2 & Reliabel \\
\hline \multicolumn{2}{|c|}{ Jumlah Butir (Items) } & 11 & \\
\hline
\end{tabular}

\section{Hasil dan Pembahasan}

\subsection{Pengumpulan Data Penelitian}

Data dikumpulkan dengan cara membagikan kuisioner ke masing-masing institusi pendidikan vokasi komputerisasi akuntansi di Propinsi Lampung. Proses pengumpulan data dilakukan mulai 25 Juni 2013 sampai dengan 12 Juli 2013. Kuisioner yang digunakan adalah sebanyak 335 atau $93 \%$ dari jumlah yang telah disebarkan. Rincian hasil pengumpulan data dapat dilihat pada tabel 4.1. berikut ini:

Tabel 4.1.

Angket (kuisioner) yang Dianalisis

\begin{tabular}{|l|c|c|}
\hline \multicolumn{1}{|c|}{ Keterangan } & Jumlah & Persentase \\
\hline $\begin{array}{l}\text { Angket (kuisioner) yang } \\
\text { disebarkan }\end{array}$ & 360 & $100 \%$ \\
\hline $\begin{array}{l}\text { Angket (kuisioner) yang } \\
\text { dikembalikan }\end{array}$ & 346 & $96 \%$ \\
\hline $\begin{array}{l}\text { Angket (kuisioner) yang } \\
\text { tidak lengkap }\end{array}$ & 11 & $3 \%$ \\
\hline $\begin{array}{l}\text { Angket (kuisioner) yang } \\
\text { digunakan }\end{array}$ & $\mathbf{3 3 5}$ & $\mathbf{9 3 \%}$ \\
\hline
\end{tabular}

(Sumber: Lampiran A)

\subsection{Karakteristik Responden Penelitian}

Karakteristik responden berdasarkan sex (jenis kelamin) dan penguasaan perangkat lunak. Dari data yang digunakan diketahui jumlah mahasiswa wanita adalah $56 \%$, lebih banyak dibandingkan dengan mahasiswa pria yaitu $44 \%$. Analisis tidak membedakan gender, penelitian ini hanya memfokuskan intention dari mahasiswa vokasi komputerisasi akuntansi secara keseluruhan. Ikhtisar pada tabel 4.2. adalah sebagai informasi penelitian penelitian.

Tabel 4.2 Responden Berdasarkan Sex

\begin{tabular}{|l|c|c|}
\hline \multicolumn{1}{|c|}{ Keterangan } & Frequency & $\begin{array}{c}\text { Valid } \\
\text { Percent }\end{array}$ \\
\hline Pria & 146 & $44 \%$ \\
\hline Wanita & 189 & $56 \%$ \\
\hline Jumlah & $\mathbf{3 3 5}$ & $\mathbf{1 0 0 \%}$ \\
\hline
\end{tabular}

(Sumber: Lampiran A)

Karakteristik responden berikutnya adalah berdasarkan penguasaan (kompetensi) menggunakan perangkat lunak basis data. Dari data diketahui bahwa $52 \%$ responden cenderung belum menguasai perangkat lunak basis data (database software). Informasi ini bisa sebagai dasar analisis terhadap variabel intention menggunakan perangkat lunak basis data pada mahasiswa vokasi komputerisasi akuntansi.

Tabel 4.3.

Penguasaan Perangkat Lunak Basis Data

\begin{tabular}{|l|c|c|}
\hline \multicolumn{1}{|c|}{ Jumlah } & Frequency & $\begin{array}{c}\text { Valid } \\
\text { Percent }\end{array}$ \\
\hline 0 Jenis Database Software & 173 & $52 \%$ \\
\hline 1 Jenis Database Software & 141 & $42 \%$ \\
\hline$>$ 1 Jenis Database Software & 21 & $6 \%$ \\
\hline
\end{tabular}


Jumlah

\section{(Sumber: Lampiran A)}

Berdasarkan tabel 4.3 diketahui bahwa 173 mahasiswa atau $52 \%$ adalah belum menguasai perangkat lunak basis data, sedangkan 162 mahasiswa atau $48 \%$ sudah menguasai perangkat lunak basis data. Dari 162 mahasiswa responden, 141 mahasiswa menguasai 1 jenis dan 21 mahasiswa menguasai lebih dari 1 jenis perankat lunak basis data (database software).

\subsection{Uji Validitas dan Reliabilitas dalam Sampel} Besar

Kuisioner yang disebarkan kepada populasi mahasiswa vokasi komputerisasi akuntansi di Propinsi Lampung disusun pada awalnya terdiri dari 34 butir (item) pertanyaan yang diambil dari penelitian terdahulu. Setelah melakukan penelitian uji coba terhadap sampel kecil didapat 21 butir (item) yang dianggap valid. Butir-butir (items) pada daftar pertanyaan (kuisioner) yang digunakan adalah seperti pada tabel 4.4. berikut ini:

\section{Tabel 4.4.}

Sumber Kuisioner yang Digunakan

\begin{tabular}{|c|c|c|}
\hline Item No. & Item Statements & Referensi \\
\hline & $\begin{array}{l}\text { I could complete the job using the software } \\
\text { package... }\end{array}$ & \multirow{5}{*}{$\begin{array}{l}\text { Comp } \\
\text { eau and } \\
\text { Higgins } \\
(1995)\end{array}$} \\
\hline CSE4 & $\begin{array}{l}\text {...if I had seen someone else using it before } \\
\text { trying }\end{array}$ & \\
\hline CSE5 & $\begin{array}{l}\text {...if I could call someone for help if I got } \\
\text { stuck. }\end{array}$ & \\
\hline CSE6 & ...if someone else had helped me get started & \\
\hline CSE9 & ...if someone showed me how to do it first & \\
\hline CLOC1 & $\begin{array}{l}\text { I could probably do just about anything I } \\
\text { need to with computers }\end{array}$ & \multirow{2}{*}{$\begin{array}{l}\text { Kay, R. H. } \\
\text { (1990), } \\
\text { Donnelly, } \\
\text { et al. } \\
(2003)\end{array}$} \\
\hline CLOC2 & $\begin{array}{l}\text { Ifeel I need an experienced person nearby } \\
\text { when I use the computer }\end{array}$ & \\
\hline CLOC4 & $\begin{array}{l}\text { I need someone to tell me the best way to use } \\
\text { computer }\end{array}$ & \multirow{5}{*}{$\begin{array}{l}\text { Kay, R. H. } \\
(1990) \text {, } \\
\text { Donnelly, } \\
\text { et al. } \\
(2003)\end{array}$} \\
\hline CLOC5 & $\begin{array}{l}\text { I feel confident about using the computer to } \\
\text { store importan information }\end{array}$ & \\
\hline CLOC7 & $\begin{array}{l}\text { If I had a problem using the computer, I } \\
\text { could solve it one way or another }\end{array}$ & \\
\hline ITU1 & $\begin{array}{l}\text { Assumming I had Access to (...), I intend to } \\
\text { use it. }\end{array}$ & \\
\hline ITU2 & $\begin{array}{l}\text { Given that I had access to (. . .), I predict I } \\
\text { would use it. }\end{array}$ & \\
\hline
\end{tabular}

( Likert Ordinal 1 sampai 5)

Data yang sebelumnya bertipe ordinal (Likert 1-5) telah dirubah ke tipe interval menggunakan metode Successive Interval memanfaatkan Add in pada MS Excel $2007^{\mathrm{TM}}$. Pengubahan data ordinal ke interval diperkenankan dan disarankan jika analisis data dengan model SEM menggunakan tools AMOS ${ }^{\mathrm{TM}}$ (Ghozali, 2005).

Pada tabel 4.5. disajikan validitas sampel besar membandingkan r_hitung (corrected item total correlation) dibandingkan dengan $r$ _tabel dengan tingkat signifikan 0,05 untuk mengetahui valid atau tidaknya butir (item) yang diajukan dalam kuisioner. Dari tabel 4.5. diketahui bahwa 21 item adalah valid dan dapat digunakan dalam analisis data selanjutnya.

Tabel 4.5.

Validitas Sampel Besar Penelitian

\begin{tabular}{|c|c|c|c|c|c|}
\hline No. & Items & $\begin{array}{c}\text { Scale } \\
\text { Variance }\end{array}$ & $\begin{array}{c}\text { Correct } \\
\text { ed }\end{array}$ & $\begin{array}{c}\text { Cronba } \\
\text { ch's }\end{array}$ & Validity \\
\hline
\end{tabular}

\begin{tabular}{|l|l|r|r|r|l|}
\hline & & $\begin{array}{c}\text { if Item } \\
\text { Deleted }\end{array}$ & $\begin{array}{c}\text { Item- } \\
\text { Total } \\
\text { Correla } \\
\text {-tion }\end{array}$ & $\begin{array}{c}\text { Alpha } \\
\text { if Item } \\
\text { Deleted }\end{array}$ & \\
\hline 1 & CSE4 & 4,648 &, 341 &, 688 & Valid \\
\hline 2 & CSE5 & 4,663 &, 309 &, 709 & Valid \\
\hline 3 & CSE6 & 3,513 &, 638 &, 489 & Valid \\
\hline 4 & CSE9 & 3,682 &, 591 &, 526 & Valid \\
\hline 5 & CLOC1 & 9,255 &, 381 &, 835 & Valid \\
\hline 6 & CLOC2 & 7,956 &, 668 &, 754 & Valid \\
\hline 7 & CLOC4 & 7,577 &, 723 &, 736 & Valid \\
\hline 8 & CLOC5 & 7,797 &, 655 &, 757 & Valid \\
\hline 9 & CLOC7 & 8,099 &, 584 &, 779 & Valid \\
\hline 10 & ITU1 &, 775 &, 625 & & Valid \\
\hline 11 & ITU2 &, 651 &, 625 & & Valid \\
\hline
\end{tabular}

Hasil reliabilitas terhadap 21 item pertanyaan seperti pada tabel 4.6 menunjukkan bahwa semua item pada sampel besar adalah reliabel. Angka Cronbach's Alpha menunjukkan memenuhi ketentuan di atas 0,7 adalah empat variabel yaitu CLOC, , dan ITU. Sedangkan variabel CSE memenuhi ketentuan reliabel di atas angka C'Alpha yaitu sebesar 0,6 yang dapat terdukung sebagai reliabel.

Tabel 4.6.

Reliabilitas Sampel Besar Penelitian

\begin{tabular}{|l|l|c|c|c|}
\hline & \multicolumn{1}{c|}{$\begin{array}{c}\text { Variable } \\
\text { Alpha }\end{array}$} & $\begin{array}{c}\text { N of } \\
\text { Items }\end{array}$ & Reliability \\
\hline CSE & $\begin{array}{l}\text { Computer Self- } \\
\text { efficacy }\end{array}$ &, 681 & 4 & Reliabel \\
\hline CLOC & $\begin{array}{l}\text { Computer Locus } \\
\text { of Control }\end{array}$ &, 811 & 5 & Reliabel \\
\hline ITU & Intention to Use &, 767 & 2 & Reliabel \\
\hline & & & 11 & \\
\hline
\end{tabular}

\subsection{Analisis Data dengan Pendekatan SEM}

Data yang telah disiapkan berformat MS. Excel ${ }^{\mathrm{TM}}$, merupakan data yang didapat dari responden dengan tipe ordinal (Likert 1-5) yang telah dirubah ke tipe interval dengan metode Successive Interval (MSI). Langkahlangkahnya telah diuraikan metode penelitian. Subbab berikutnya akan menguraikan tahapan analisis dengan pendekatan Structural Equation Modeling (SEM)

\subsubsection{Path Diagram Model Penelitian}

Sampel yang diukur adalah sebanyak 335 data responden. Sampel sebanyak ini telah memenuhi syarat untuk dilakukan estimasi dan pengujian struktur model. Model yang diukur akan dibagi menjadi 2 grup yaitu personality dan cognitive. Pembagian ini untuk mengetahui pengaruh dari variabel yang di ukur (observed) dan variabel laten. Gambar 4.1 merupakan path diagram model-model struktural yang dibangun menggambarkan hubungan-hubungan yang ada diantara variabel-variabel laten masing-masing personality. 


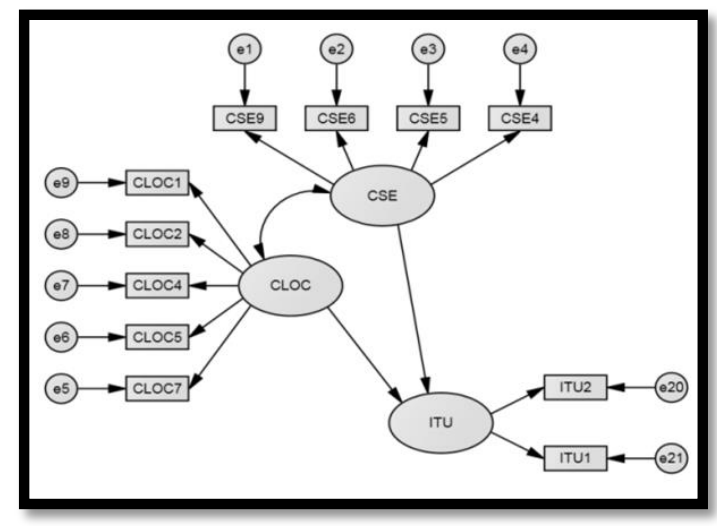

Gambar 4.1. Path Diagram Personality

Observed, endogenous variables:

- Computer self-efficacy (CSE) dengan 4 butir (items) yaitu CSE4, CSE5,CSE6 dan CSE9;

- Computer locus of control (CLOC) dengan 5 items yaitu CLOC1, CLOC2, CLOC4, CLOC5 dan CLOC7;

- Intention to use (ITU) dengan 2 items yaitu ITU1 dan ITU2.

Estimasi terhadap model juga memunculkan unobserved, endogenous variable yaitu ITU. Sedangkan unobserved lainnya adalah exogenous variables yaitu CSE, CLOC, e1, e2, e3, e4, e5, e6, e7, e8, e9, e20 dan $\mathrm{e} 21$.

Analisis SEM mensyaratkan identifikasi model harus termasuk dalam kategori over-identified. Pada tabel 4.7. yang merupakan output AMOSTM menunjukkan nilai degree of freedom $(\mathrm{df})$ adalah sebesar 184. Indikasi dari $d f$ model termasuk kategori over-identified karena $d f$ bernilai positif, artinya tahap analisis data dengan SEM bisa dilanjutkan ke tahap berikutnya.

Tabel 4.7.

Computation of Degrees of Freedom

\begin{tabular}{|r|r|}
\hline Number of distinct sample moments: & 231 \\
\hline Number of distinct parameters to be estimated: & 47 \\
\hline Degrees of freedom (231 - 47): & 184 \\
\hline
\end{tabular}

Pada gambar 4.2. di bawah ini adalah gambaran model structural dari pengaruh personality dan cognitive terhadap intention penggunaan perangkat lunak basis data.

\subsubsection{Evaluasi Estimasi Model}

Evaluasi hasil terhadap model yang digunakan harus memenuhi asumsi-asumsi SEM. Beberapa asumsi SEM yang harus dipenuhi yaitu: ukuran sampel yang memadai, data yang terdistribusi normal, penanganan data yang outlier dan tidak adanya multikolinearitas. Dari data pada model awal diketahui bahwa :

a. Ukuran Sampel

Sampel data yang diuji sebanyak 335 data adalah memenuhi syarat jumlah data yang disarankan untuk pengujian SEM, data haruslah melebihi 100 data;

b. Normalitas Data
Dari hasil output AMOSTM diketahui bahwa data belum terdistribusi normal secara multivariat. Ini bisa diketahui dari nilai $c r$. data keseluruhan sebesar 45,696. Nilai yang dihasilkan berada diluar rentang nilai $c r$. dari data terdistribusi normal yaitu antara $2.58 \mathrm{s.d}+2,58$. Berdasarkan literature, jika normalitas data belum tercapai setelah data outlier dihapus, maka penambahan data direkomendasikan. Penelitian tetap bisa dilakukan jika data berjumlah $>50$ (Hair et al); dan estimasi MLE (default yang terdapat pada AMOS $^{\mathrm{TM}}$ ) masih bisa digunakan meskipun asumsi normalitas (setelah menghapus outlier) belum bisa terpenuhi;

c. Data Outlier

Data outlier dapat diketahui dari nilai mahalanobis distance yang mencantumkan nilai p1 dan p2. Suatu data termasuk outlier jika nilai p1 dan p2 yang dihasilkan bernilai kurang dari 0,05. Dari lampiran output data diketahui bahwa 34 data memiliki nilai p1 dan p2<0,05. Jadi ada 34 data outlier yang dihapus dari analisis selanjutnya, sehingga data yang tersisa adalah 301 sampel responden . Dapat diketahui dari lampiran output, setelah ke 34 data yang outlier dihapus, semua data bernilai p1 dan p2 $>0,05$. Sehingga permasalahan data outlier sudah dapat diatasi;

d. Multikolinearitas

Terdapatnya multikolinearitas apabila terdapat nilai korelasi antar indikator yang nilainya $\geq 0,9$. Nilai korelasi antar indikator pada output AMOS ${ }^{\mathrm{TM}}$ terlihat tidak terdapat nilai korelasi antar indikator yang bernilai $\geq 0,9$. Jadi asumsi tidak terdapatnya multikolinearitas terpenuhi.

\subsubsection{Pengujian Kelayakan Model}

Tahapan pengujian model penelitian adalah dengan pengujian validitas measurement model dan structural model. Pengujian GOF (goodness of fit) dilakukan untuk mengetahui seberapa fit model dengan data yang diperoleh. Berdasarkan output path diagram, hasil pengujian goodness of fit dibuat ikhtisar yang dapat dilihat pada tabel 4.8 yang memuat GOF index, cut-off value, nilai, dan keterangan tingkat fit yang dihasilkan.

Tabel 4.8 .

Ikhtisar Hasil GOF Pengujian Model Awal

\begin{tabular}{|l|c|c|c|}
\hline \multicolumn{1}{|c|}{$\begin{array}{c}\text { Goodness of } \\
\text { Fit Index }\end{array}$} & $\begin{array}{c}\text { Cut-off } \\
\text { Value }\end{array}$ & $\begin{array}{c}\text { Nilai pada } \\
\text { Model }\end{array}$ & Keterangan \\
\hline $\begin{array}{l}\text { Chi-square } \\
\left(\chi^{2}\right)\end{array}$ & $\begin{array}{c}\text { Semakin } \\
\text { kecil } \\
\text { semakin baik }\end{array}$ & 3505,571 & \\
\hline CMIN/DF & $<2,00$ & 19,052 & poor fit \\
\hline $\begin{array}{l}P \\
(\text { probability) }\end{array}$ & $>0,05$ & 0,000 & poor fit \\
\hline RMSEA & $<0,08$ & 0,232 & poor fit \\
\hline GFI & $>0,90$ & 0,531 & poor fit \\
\hline TLI & $>0,90$ & 0,396 & poor fit \\
\hline
\end{tabular}

respesifikasi model penelitian. Respesifikasi bertujuan untuk mendapatkan model penelitian yang fit sebagai syarat untuk melanjutkan ke pengujian hipotesis.

Respesifikasi model dilakukan dengan cara memodifikasi atau menghapus indicator (item) yang 
memiliki factor loading < 0,50; menambahkan variabel (jika tersedia) atau mengurangi variabel penelitian.

Tabel 4.9.

Ikhtisar Hasil GOF Pengujian Model Setelah Modifikasi

\begin{tabular}{|l|c|c|c|}
\hline $\begin{array}{c}\text { Goodness of } \\
\text { Fit Index }\end{array}$ & $\begin{array}{c}\text { Cut-off } \\
\text { Value }\end{array}$ & $\begin{array}{c}\text { Nilai } \\
\text { pada } \\
\text { Model }\end{array}$ & Keterangan \\
\hline $\begin{array}{l}\text { Chi-square } \\
\left(\chi^{2}\right)\end{array}$ & $\begin{array}{c}\text { Semakin } \\
\text { kecil } \\
\text { semakin } \\
\text { baik }\end{array}$ & 163,604 & \\
\hline CMIN/DF & $<2,00$ & 1,437 & good fit \\
\hline $\begin{array}{l}P \\
(\text { probability })\end{array}$ & $>0,05$ & 0,063 & good fit \\
\hline RMSEA & $<0,08$ & 0,084 & reasonable fit \\
\hline GFI & $>0,90$ & 0,937 & good fit \\
\hline TLI & $>0,90$ & 0,965 & good fit \\
\hline
\end{tabular}

Dari hasil pengujian GOF pada tabel 4.9., diketahui bahwa model modifikasi dengan data yang ada dinyatakan fit. Dengan fit-nya model maka pengujian hipotesis bisa dilakukan. Pengujian hipotesis dilakukan dengan melihat C.R. (critical ratio) yang terdapat pada tabel 4.10 .

Tabel 4.10.

Regression, C.R. and Standarized Regression Weights

\begin{tabular}{|c|c|c|c|c|c|c|}
\hline \multicolumn{3}{|c|}{ Path } & $\begin{array}{c}\text { Estimate } \\
\text { Reg.W }\end{array}$ & S.E. & C.R. & $\begin{array}{c}\text { Estimate } \\
\text { Stand Reg.W }\end{array}$ \\
\hline ITU & $<$ & CSE & $-0,365$ & 0,163 & $-2,244$ & $-0,238$ \\
\hline ITU & $<$ & CLOC & 0,441 & 0,205 & 2,155 & 0,229 \\
\hline ITU & $<$ & $\mathrm{e} 22$ & 0,747 & par_20 & & 0,775 \\
\hline CSE9 & $<$ & CSE & 1 & & & 0,747 \\
\hline CSE6 & $<$ & CSE & 1,111 & 0,097 & 11,492 & 0,826 \\
\hline CLOC7 & $<$ & CLOC & 1 & & & 0,624 \\
\hline CLOC5 & $<$ & CLOC & 1,312 & 0,115 & 11,449 & 0,812 \\
\hline CLOC4 & $<$ & CLOC & 1,459 & 0,127 & 11,469 & 0,884 \\
\hline CLOC2 & $<-$ & CLOC & 1,405 & 0,124 & 11,302 & 0,845 \\
\hline ITU2 & $<-$ & ITU & 1 & & & 1,195 \\
\hline ITU1 & $<-$ & ITU & 0,413 & 0,064 & 6,476 & 0,564 \\
\hline
\end{tabular}

Pengujian hipotesis dengan membandingkan C.R. pada tabel 4.10. dengan nilai kritis (identik dengan $t$ hitung) adalah 1,65 pada tingkat signifikansi 0,05 atau 5\%. Jika nilai C.R. lebih besar daripada nilai kritisnya (tingkat signifikansi $\mathrm{p}<0,05)$, maka hipotesis yang diajukan terdukung. Tetapi apabila C.R. belum dapat mencapai nilai kritisnya maka hipotesis tidak terdukung.

\subsubsection{Pengujian Hipotesis}

Berdasarkan ikhtisar hasil pada tabel 4.10. maka dapat diuraikan hasil uji hipotesisnya sebagai berikut: a. Computer Self-efficacy (CSE) berpengaruh terhadap Intention penggunaan perangkat lunak basis data (ITU). Dari output AMOSTM path ITU <--- CSE, diketahui nilai C.R. sebesar -2,244. Nilai ini lebih kecil dari nilai kritis 1,65, yang dapat diartikan bahwa secara statistis CSE tidak berpengaruh signifikan terhadap ITU, sehingga pernyataan hipotesis 1 pada penelitian ini tidak terdukung.

b. Computer Locus of Control (CLOC) berpengaruh terhadap Intention penggunaan perangkat lunak basis data (ITU). Berdasarkan hasil pada tabel 4.10. path ITU <--- CLOC, diketahui nilai C.R. bernilai 2,155. Nilai ini lebih besar dari nilai kritis 1,65. Dapat disimpulkan bahwa C.R.>1,65 adalah menunjukkan bahwa secara statistis CLOC berpengaruh terhadap ITU. Jadi pada penelitian ini hipotesis 2 terdukung.

c. Dari hasil output AMOSTM diketahui C.R. personality (trait) yang diwakili oleh CSE dan CLOC dibandingkan dengan C.R. cognitive (style) yang diwakili oleh PU dan PEOU maka diketahui bahwa, cognitive lebih berpengaruh terhadap ITU perangkat lunak basis data. path ITU <--- PEOU adalah 8,541>1,65; path ITU <--- PU adalah 8,133>1,65; Path ITU <--- CLOC adalah 2,155>1,65; dan Path ITU <--- CSE adalah $-2,244<1,65$. Hasil dari penelitian ini menunjukkan bahwa secara statistis cognitive lebih berpengaruh signifikan terhadap intention penggunaan perangkat lunak basis data (ITU) jika dibandingkan dengan personality (trait).

\subsection{Kesimpulan Hasil Uji Hipotesis}

Hasil pengujian terhadap empat hipotesis yang diajukan adalah berdasarkan pendekatan Structural Equation Modeling (SEM) berbasis covariance menggunakan tools IBM ${ }^{\circledR}$ SPSS ${ }^{\circledR}$ AMOS $^{\mathrm{TM}}$ versi 21 dengan membandingkan C.R. (t_hitung) dengan nilai kritis (t_tabel). Tabel 4.11. menunjukkan hasil uji hipotesis yang memberikan kesimpulan pengukuran hubungan pengaruh antar variabel penelitian.

Tabel 4.11. Hasil Uji Hipotesis

\begin{tabular}{|c|c|c|c|c|c|}
\hline $\begin{array}{c}\text { Hipo- } \\
\text { tesis }\end{array}$ & $\begin{array}{c}\text { Estim. } \\
\text { Reg.W }\end{array}$ & $\begin{array}{c}\text { Estim. } \\
\text { Stand. } \\
\text { Reg.W }\end{array}$ & $\begin{array}{c}\text { C.R. } \\
\text { (t_hit.) }\end{array}$ & $\begin{array}{c}\text { Nilai } \\
\text { Kritis } \\
\text { (t_tab. } \\
\text { ) sig. } \\
\mathbf{0 , 0 5}\end{array}$ & Hasil \\
\hline H1 & $-0,365$ & $-0,238$ & $-2,244$ & 1,65 & $\begin{array}{c}\text { H1 tidak } \\
\text { terdukung }\end{array}$ \\
\hline H2 & 0,441 & 0,229 & 2,155 & 1,65 & $\begin{array}{c}\text { H2 } \\
\text { terdukung }\end{array}$ \\
\hline
\end{tabular}

Berdasarkan tabel 4.11. kesimpulan akhir yang diperoleh untuk setiap hipotesis yang diajukan dalam penelitian ini adalah sebagai berikut:

\section{H1 : Computer Self-efficacy (CSE) berpengaruh positif terhadap Intention penggunaan perangkat lunak basis data (ITU)}

Hasil pengujian menunjukkan bahwa hipotesis pertama tidak terdukung. Artinya intention penggunaan perangkat lunak basis data (ITU) pada mahasiswa vokasi komputerisasi akuntansi di Propinsi Lampung, tidak dipengaruhi oleh computer self-efficacy (CSE). Meskipun mahasiswa memiliki CSE pada tingkatan pemahaman tertentu, namun itu tidak berpengaruh positif terhadap intention menggunakan perangkat lunak basis data. Hasil 
temuan ini sejalan dengan hasil penelitian Fuadi (2009) yang mengukur CSE tidak berpengaruh positif terhadap minat (intention) penggunaan internet banking. Serupa dengan hasil penelitian ini, Zainol dan Nelson (2011) secara deskriptif menemukan bahwa, persepsi mahasiswa akuntansi di Malaysia yang mengalami kesulitan dalam menguasai perangkat lunak basis data dengan computer self-efficacy instrument yaitu owning computer, gender, working experience, ICT skills dan future role (interest) terhadap penggunaan perangkat lunak basis data MS Access $^{\mathrm{TM}}$ dalam membuat prototype basis data akuntansi.

Penelitian ini menemukan intention menggunakan perangkat lunak basis data tidak dipengaruhi oleh computer self-efficacy. Ada kemungkinan hal ini disebabkan oleh anggapan sebagian besar mahasiswa pada sampel, terhadap perangkat lunak basis data. Anggapan bahwa perangkat lunak basis data rumit dan tidak menyenangkan. Hanya sedikit mahasiswa yang memahami bahwa anggapan itu keliru. Dengan memiliki intention terhadap basis data, akan menghantarkan kepada perilaku mahasiswa untuk menguasai pengolahan data menjadi informasi pada suatu sistem informasi akuntansi.

$\mathrm{H2}$ : (Internal) Computer Locus of Control (CLOC) berpengaruh positif terhadap Intention penggunaan perangkat lunak basis data (ITU)

Hasil pengujian menunjukkan bahwa hipotesis kedua terdukung. Artinya intention penggunaan perangkat lunak basis data (ITU) pada mahasiswa vokasi komputerisasi akuntansi di Propinsi Lampung, dipengaruhi oleh computer locus of control (CLOC). Mahasiswa vokasi komputerisasi akuntansi dengan internal CLOC memiliki intention yang tinggi terhadap penggunaan perangkat lunak basis data. Sebaliknya bagi mahasiswa vokasi komputerisasi akuntansi yang memiliki eksternal CLOC memiliki intention yang rendah terhadap penggunaan perangkat lunak basis data. Hasil penelitian ini sejalan dengan Kay (1990), yang menemukan bahwa computer locus of control berpengaruh positif terhadap computer literacy pengguna (user).

\section{Simpulan dan Rekomendasi \\ 5.1 Simpulan}

Penelitian ini bertujuan untuk mengukur pengaruh personality terhadap intention penggunaan perangkat lunak basis data pada mahasiswa vokasi komputerisasi akuntansi. Kuisioner yang dianalisis adalah sebanyak 335 dengan 21 indikator/item. Setelah pengujian asumsi SEM didapat data yang digunakan pada tahap uji kelayakan model atau goodness of fit (GOF) adalah 301 data sampel dengan 16 indikator. Hasil yang didapat setelah GOF terpenuhi, menghasilkan estimasi terhadap pengujian empat hipotesis yang menyimpulkan bahwa, secara statistis hipotesis kesatu tidak terdukung, sedangkan hipotesis kedua, terdukung.

Tujuan penelitian yang pertama adalah untuk mendapatkan bukti empiris dengan menguji faktor-faktor personality mahasiswa vokasi komputerisasi akuntansi yaitu computer self-efficacy (CSE) dan computer locus of control (CLOC) dapat mempengaruhi niat (intention) terhadap penggunaan perangkat lunak basis data. Kesimpulan akhir dari pengujian hipotesis kesatu disimpulkan bahwa intention (ITU) menggunakan perangkat lunak basis data tidak dipengaruhi secara positif oleh computer self-efficacy (CSE). Sedangkan hasil uji hipotesis kedua disimpulkan bahwa intention (ITU) menggunakan perangkat lunak basis data dipengaruhi secara positif oleh computer locus of control (CLOC). Meskipun berpengaruh secara positif, koefesien regresinya rendah $(\mathrm{RW}=0,441$ dan $\mathrm{SRW}=0,229)$. Pada penelitian ini, disimpulkan bahwa dari dua faktor personality (CSE dan CLOC) hanya CLOC (kelompok internal) yang mempengaruhi secara positif intention penggunaan perangkat lunak basis data.

dibandingkan dengan persepsi (cognitive) dalam mengukur niat (intention) pengunaan internet. Sedangkan Nazar (2008) dalam temuannya dinyatakan bahwa cognitive (perceived usefulness and perceived ease of use) terhadap niat (intention) menggunakan internet lebih berpengaruh daripada personality (computer anxiety, affect \& trust). Dari kedua penelitian itu terdapat perbedaan temuan penelitian McElroy (2007) dan Nazar (2008).

Pada penelitian ini model cognitive lebih mempengaruhi intention pengunaan perangkat lunak basis data dibandingkan model personality. Kesimpulan ini didasari atas temuan perbandingan hasil Critical Ratio (C.R.) dan koefesien regression weights (RW) serta koefesien standardized regression weights (SRW) masingmasing variabel. Berikut ini adalah tabel 5.1. yang menyajikan perbandingan masing-masing kelompok faktor personality.

Tabel 5.1.

Tingkatan Pengaruh antar Variabel

\begin{tabular}{|c|c|c|c|c|c|c|c|}
\hline \multicolumn{3}{|c|}{ Path } & $\begin{array}{c}\text { Esti-mate } \\
\text { Reg.W }\end{array}$ & $\begin{array}{l}\text { Esti-mate } \\
\text { Stand. } \\
\text { Reg. W }\end{array}$ & C.R. & Label & Ket. \\
\hline ITL & $<$ & CLOC & 0,441 & 0,229 & 2,155 & par_13 & Per. \\
\hline ITT & $<\ldots$ & CSE & $-0,365$ & $-0,238$ & $-2,244$ & par_12 & Per. \\
\hline
\end{tabular}

Berdasarkan urutan pengaruh variabel pada tabel 5.1., dapat disimpulkan bahwa faktor cognitive (Cog.) yang berpengaruh lebih kuat dibandingkan personality (Per.). Berdasarkan nilai koefisien SRW $<0,5$, disimpulkan intention mahasiswa vokasi komputerisasi akuntansi di Propinsi Lampung relatif masih rendah dalam menggunakan perangkat lunak basis data.

\subsection{Keterbatasan}

Beberapa hal yang perlu diperhatikan dalam kesimpulan akhir, yaitu adanya beberapa keterbatasan pada penelitian ini yang perlu penulis ungkapkan:

1. Penelitian ini dilakukan pada rentang waktu yang sempit, sampel yang relative terbatas pada area geografi tertentu dan alat statistis tertentu;

2. Persepsi mahasiwa terhadap questionnaire berbahasa asing yang dialihbahasakan ke bahasa Indonesia, sangat mungkin menimbulkan persepsi yang belum tepat.

Karena keterbatasan itu, kesimpulan belum bisa digeneralisir secara luas terhadap populasi lainnya.

\subsection{Rekomendasi}

Berdasarkan keterbatasan penelitian, rekomendasi yang bisa diajukan untuk penelitian berikutnya adalah: 
1. Sampel dan populasi yang diperluas, waktu yang diperpanjang, tidak hanya pada mahasiswa tetapi juga bisa diperluas terhadap pengajar, instruktur atau dosen. Selain itu perlu juga membandingkan hasil analisis menggunakan alat bantu statistis yang lain. Hal ini untuk memastikan kekuatan hasil analisis yang menghasilkan kesimpulan yang lebih kuat dari penelitian sebelumnya;

2. Perlunya perlakuan atau treatment sebelum mahasiswa menjawab angket (questionnaire). Metode yang digunakan disarankan murni eksperimen atau menggunakan lab eksperimen, dengan mengembangkan indikator dan model penelitian dari variabel personality lainnya.

\section{Daftar Pustaka}

[1] Arbuckle, James L., 2012. "IBM ${ }^{\circledR} \quad$ SPSS ${ }^{\circledR} \quad$ Amos $^{\mathrm{TM}}$ 21User's Guide”. New York: IBM Corp. Published.

[2] Compeau, D. R., and Higgins, C. A. 1995a "Application of Social Cognitive Theory to Training for Computer Skills," Information Systems Research (6:2), pp. 118-143.

[3] Compeau, Deborah \& Hinggis, 1995b, "Computer Self Efficacy: Development of Measure and Initial Test", MIS Quarterly, Vol 19 No. 12.

[4] Davis, F. D., Bagozzi, R. P., and Warhsaw, P. R.. 1989. "User Acceptance of Computer Technology: A Comparison of Two Theoretical Models," Management Science (35:8), pp. 982-1003.

[5] DeLone, William H. \& Ephraim R. McLean. 1988. "Information Systems Success: The Quest for the Dependent Variable". Washington D.C.: The Institute of Management Sciences

[6] Ghozali Imam, 2005. Analisis Multivariate dengan Program SPSS. Edisi 3, Badan Penerbitan Universitas Diponegoro, Semarang.

[7] Hair, J., Anderson, R., Tatham, R. \& Black, W. 2006. "Multivariate Data Analysis". Upper Saddle River, NJ : Prentice Hall.

[8] Hair, J.A., Rolph E. Anderson, Ronald L. Tathtam, William C. Black, 1995, Multivariate Data Analysis With Readings, Engelewood Cliffs, NJ : Prentice-Hall,Inc.

[9] Igbaria, M., Zinatelli, N., Cragg, P. \& Cavaye, L.M. 1997. "Personal Computing Acceptance Factors in Small Firms: A Structural Equation Model". MIS Quarterly 21(3): 279302.

[10] Kay, R. H. .1990. "The Relation Between Locus of Control and Computer Literacy. Journal of Research on Computing in Education, 22(4), 464-474.

[11] Undang-undang RI Nomor 12 Tahun 2012, Tentang Pendidikan Tinggi.

[12] Wilkinson, Cerullo., \& Raval Wong. 2000. "Accounting Information System”. Fourth Edition, New York : John Wiley and Sons Inc. 